\title{
ВИРІШУВАТИ НОВІ ЗАВДАННЯ ОНОВЛЕНИМ СКЛАДОМ
}

Виступ на круглому столі «Національне агентство із забезпечення якості вищої освіти 2019-2021: ключові досягнення, виклики та перспективи» 28 вересня 2021 p.

https://doi.org/10.37472/2707-305X-2021-3-2-3-1

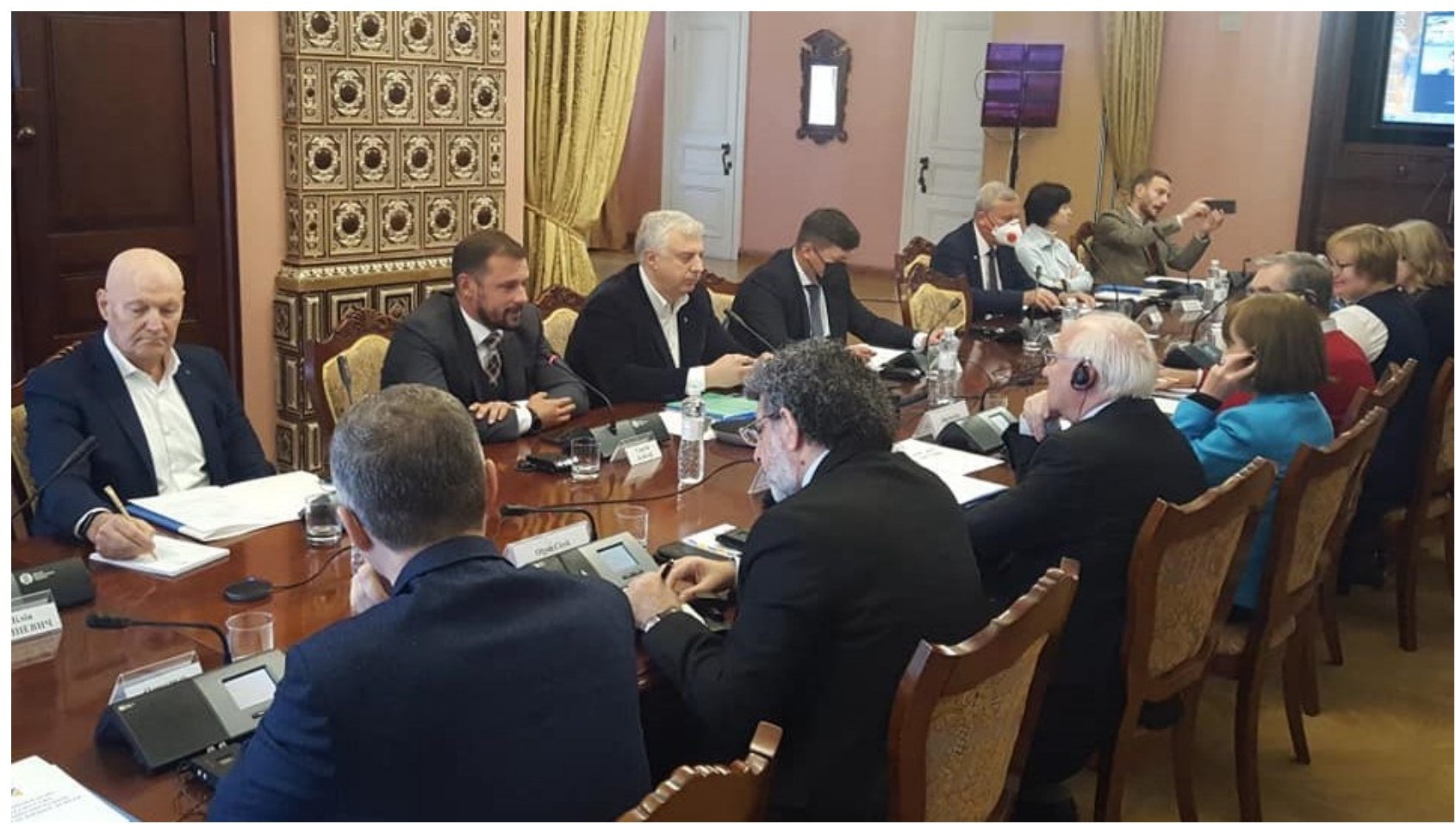
Фото: https://www.facebook.com/mychailo.wynnyckyj

\section{ЛУГОВИЙ}

\section{Володимир Іларіонович} доктор педагогічних наук, профресор, дійсний член (академік) НАПН України, перший віце-президент Національної академії педагогічних наук України, м. Київ, Україна

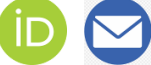

Анотація. У виступі відзначено позитивну роль нинішнього складу Національного агентства із забезпечення якості вищої освіти у період його становлення і стабілізаиії роботи у 2019-2021 рр. 3помін досягнень наголомено на розв'язанні фундаментальної проблеми створення національної системи забезпечення якості вищої освіти на ії базовому, пороговому рівні, рівні мінімально достатньої якості із застосуванням акредитаційних процедур. Акцентовано на важливості наступності при формуванні нового складу Національного агентства. Аргументовано необхідність невідкладної відповіді оновленим складом на більш складний виклик сьогодення щодо досягнення максимально досконалої, топової якості вищої освіти в Україні на основі впровадження $і$ використання національного рейтингу закладів вищої освіти.

Ключові слова: Начіональне агентство із забезпечення якості вищої освіти; мінімально достатня якість; максимально досконала якість; вища освіта; акредитація; національний рейтинг.

Увага до наступності складу і нових завдань Національного агентства із забезпечення якості вищої освіти, про що йшлося у попередніх виступах, заслуговує на всіляку підтримку. Як колишній голова Комісії з відбору членів Національного агентства, теж 
висловлю певні побажання. Насамперед необхідно домогтися, аби був укомплектований такий новий склад Національного агентства, який за зразком роботи цього складу зможе вирішити не тільки ті завдання, які вже розпочато реалізовувати, а й відповісти на нові виклики, що постали перед вищою освітою України.

Про що йдеться? Слід однозначно сказати, що цей склад Національного агентства значною мірою вирішив важливе стратегічне завдання номер один, яке актуальне для України, і запустив національну систему забезпечення якості вищої освіти. Ця система узгоджена з принципами Болонського процесу, засадами Європейського простору вищої освіти (ЄПВО), Стандартами і рекомендаціями із забезпечення якості в ЄПВО. В iї основі акредитаційні механізми. Система працює, функціонує в стійкому режимі, не «завалиться», як це бувало на початку її створення. $€$ всі підстави вважати і цілковита впевненість, що вона буде продуктивно працювати й надалі. Тут, як кажуть, душа спокійна.

Але цією першою стратегічною задачею розвиток вищої освіти не обмежується. Адже розв'язано лише первинну, стартову задачу забезпечено системну національну процедуру досягнення мінімально достатньої, порогової, базової якості і підтягування до певного стандартизованого рівня відстаючих закладів вищої освіти. Ставиться за мету, щоб провальних закладів більше не було взагалі, а якість української вищої освіти була знаною і визнаною, прийнятною повсюдно в Європі і світі. Цим переймається Болонський процес і це вимагається Угодою про асоціацію України з Європейським Союзом.

Водночас на світовій арені існує й активно просувається останніми роками й інша стратегія розвитку вищої освіти. Вона стосується досягнення не лише мінімально достатньої, а й максимально досконалої якості. Цим, як переконує провідний досвід, зазвичай, переймають самі прогресивні країни, які бажають бути в авангарді світового розвитку. Тут справедливо говорилося про те, щоб вийти на нормальний рівень акредитації достатньо побудувати добротне внутрішнє інституційне забезпечення якості. Проте вирішення другої стратегічної задачі не достатньо покласти на рівень окремих інститутів, а потребує об'єднаних національних мотиваційних, мобілізаційних та модернізаційних зусиль. I, насамперед, потребує запровадження нового механізму моніторингу й оцінювання топової якості вищої

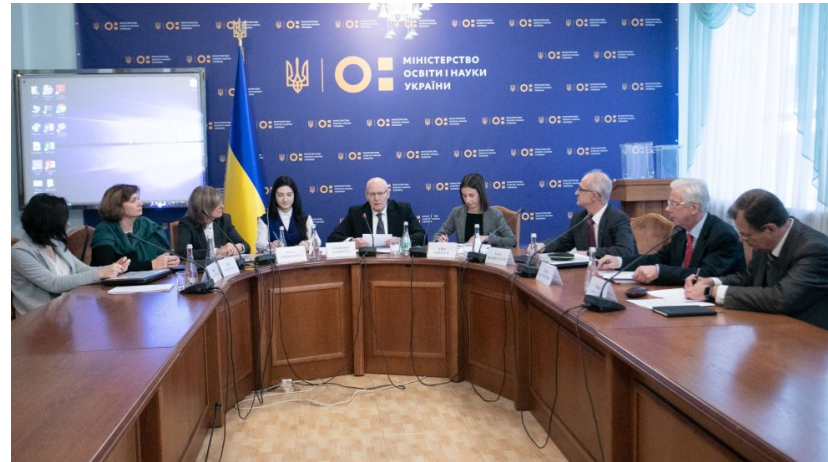

Засідання Конкурсної комісії з відбору членів Національного агентства із забезпечення якості вищої освіти 5 грудня 2018 р.

освіти шляхом рейтингування, оскільки акредитації в цьому разі недостатньо.

У Законі України «Про вищу освіту» 2014 р. закладені зачатки університетського рейтингування і унормовано, що саме до функцій Національного агентства відноситься розроблення рейтингових критеріїв. Однак тепер у цього незалежного і, сподіваємося, у перспективі достатньо фінансованого державою органу мають бути істотно розширені функції для того, щоб в Україні нарешті відбулося об'єктивне, валідне, вірогідне і зрозуміле національне університетське рейтингування. Розпочати потрібно із доповнення згаданого Закону України «Про вищу освіту» спеціальною статтею про національний рейтинг закладів вищої освіти. Це необхідно для виявлення топових закладів та їх наступної державної цільової підтримки для перетворення в університети світового класу. Таких закладів, що у групі топ500 найкращих за провідними міжнародними університетськими рейтингами Шанхайський, Таймс і К'ю Ес, сьогодні, слід констатувати, в Україні немає. Відтак будемо сподіватися, що через три роки, коли відбудеться черговий круглий стіл, підсумовуючи діяльність нового складу Національного агентства, зможемо говорити, що і стратегічне завдання номер два в Україні реалізовано. Це означатиме, що серед 63 країн/територій, учасниць загальної версії Шанхайського рейтингу, $€$ Україна, а серед 93 країн/територій в галузевій версії цього рейтингу у 54 предметних академічних галузях $€$ Україна хоча $б$ з одним українським університетом.

\section{СПИСОК ВИКОРИСТАНИХ ДЖЕРЕЛ}

Артюхов, А., Бутенко, А., Винницький, М., Денискіна, Г., Євстіфеєв, М., Єременко, О., Журавленко, В., Квіт, С., Крамаренко, К., Куницька, К., Назаров, І., Наконечна, Н., Осіюк, О., Пізнюк, Л., Стукало, Н., Терещук, В., Фініков, Т., Хименко, О., \& Шипілов, Л. (2021). Річний звіт Національного агентства із 
забезпечення якості вищої освіти (С. Квіт, О. Єременко, заг. ред.). Київ: Національне агентство із забезпечення якості вищої освіти. https:// bit.ly/3|3|ICO

Воробйова, О., Дебич, М., Луговий, В., Оржель, О., Слюсаренко, О., Таланова, Ж., \& Трима, К. (2020). Механізми оцінювання якості вищої освіти в умовах євроінтеграції : монографія (В. Луговий, Ж. Таланова, ред.). Київ: Інститут вищої освіти НАПН України. https://doi.org/10.31874/978-6177486-38-0-2020

Закон України «Про вищу освіту». (2014, 1 липня). http://zakon5.rada.gov.ua/laws/show/1556-18

Кабінет Міністрів України. (2018, 14 березня). Про затвердження переліку світових рейтингів університетів для визначення особливої категорії іноземців та осіб без громадянства, які претендують на працевлаштування в Україні (154-р). http://zakon2.rada.gov.ua/laws/show/154-2018-p

Луговий, В.І., Слюсаренко, О.М., \& Таланова, Ж.В. (2020). Моніторинг, мотивація, мобілізація задля конкурентоспроможності університетів України: механізми реалізації. Вісник Національної академії педагогічних наук України, 2(2). https:// doi.org/10.37472/2707-305X-2020-2-2-13-1

Луговий, В., Слюсаренко, О., \& Таланова, Ж. (2020). Рейтинговий розподіл та формульне фінансування українських університетів: проблема суб'єктивізму і недовіри. Міжнародний науковий журнал "Університети і лідерство», (10), 35-69. https:// doi.org/10.31874/2520-6702-2020-10-2-35-69
Міністерство освіти і науки України. (2018, 5 грудня). Обрано 22 членів НАЗЯВО - підсумок засідання Конкурсної комісії. https://mon.gov.ua/ua/news/ obrano-22-chleniv-nazyavo-pidsumok-zasidannyakonkursnoyi-komisiyi

Національне агентство із забезпечення якості вищої освіти. (2021, 28 вересня). Підсумки діяльності Національного агентства 2019-2021: ключові досягнення, виклики та перспективи [Відео]. Facebook. https://fb.watch/8pS3ma-WnJ/

Президент України. (2020, 3 червня). Про вдосконалення вищої освіти в Україні (210/2020). https:// www.president.gov.ua/documents/2102020-34045

Lugovyi, V., Slyusarenko, O., \& Talanova, Zh. (2019). University Rating \& Development: Challenges and Opportunities for Ukraine. Education: Modern Discourses, (2), 60-77. https://doi.org/10.32405/26173107-2019-1-8

Lugovyi, V., Slyusarenko, O., \& Talanova, Zh. (2020). Challenge of Developing Quality Profile of Higher Education in Ukraine. Education: Modern Discourses, (3), 57-77. https://doi.org/10.37472/2617-3107-20203-06

QS World University Rankings. (n.d.). https:// www.topuniversities.com/

$\begin{array}{lll}\text { Shanghai Ranking. } & \text { (n.d.). https:// }\end{array}$ www.shanghairanking.com/

THE World University Rankings. (n.d.). https:// www.timeshighereducation.com/world-universityrankings

\title{
TO SOLVE NEW TASKS WITH A RENEWED STAFF
}

Speech at the round table "National Agency for Quality Assurance in Higher Education 2019-2021: Key Achievements, Challenges and Prospects", September 28, 2021

\author{
Volodymyr Lugovyi \\ DSc in Education, Professor, Full Member (Academician) of NAES of Ukraine, First Vice-President \\ National Academy of Educational Sciences of Ukraine, Kyiv, Ukraine
}

Abstract. The positive role of the National Agency for Quality Assurance in Higher Education's current staff during its establishment and stabilization of work in 2019-2021 is pointed out in the report. Solving a fundamental problem of creating a national system of quality assurance in higher education at its basic, threshold, minimal sufficient quality levels using accreditation procedures is emphasized among the achievements. It is focused on the importance of continuity in the formation of the National Agency's new staff. The need for an immediate response by the renewed staff to today's more complex challenge on achieving maximum excellent, top quality of higher education in Ukraine, based on the introduction and use of national higher education institutions ranking, is argued.

Keywords: National Agency for Quality Assurance in Higher Education; minimum sufficient quality; maximum excellent quality; higher education; accreditation; national ranking. 